\title{
FOSSIL PLANTS FROM ROMANIAN DEPOSITS OF BÂCLEŞ, DOLJ DISTRICT, ROMANIA
}

\author{
NICOLAE ȚICLEANU ${ }^{1}$, PETRE ENCIU ${ }^{2}$, ION PĂTRUȚOIU ${ }^{3}$, \\ VALENTIN PARASCHIV ${ }^{1}$
}

\begin{abstract}
From the Middle Romanian lacustrine deposits of the Oltenia province, the authors describe the youngest fossil flora known until now in Oltenia. The inventory of the fossil flora includes the following taxa: Taxodium dubium, ?Platanus platanifolia, Ulmus laevis, Quercus roburoides, Q. cf. muehlenbergii, Carya serraefolia, Acer cf. tricuspidatum and Salix sp. In the Bâcleş fossil flora, Glyptostrobus europaeus, which is a thermophilous and shows a high frequency in all Oltenia area till the XV-th coal seam, is absent. Consequently, having in view the high frequency of Taxodium dubium, which indicate temperate climate conditions, the other consider that the fossil flora from Bâcleş is much more younger and marks an important cooling. From palaeofloristic point of view, the study of Bâcleş fossil flora is indicative for river meadow forest and, probably, flat plain forest environments.
\end{abstract}

KEYWORDS: Pliocene, Middle Romanian, macroflora, Oltenia.

\section{INTRODUCTION}

The important frequency of telmatic, lacustrine and riparian facies in the Pliocene deposits of Oltenia province (southwestern Romania), provides a rich palaeofloristic material, for now insufficiently known. The research made until now referred specially at the Dacian (Lower Pliocene) macroflora, the Romanian one (Upper Pliocene) being much less known. In this context, the presentation of some fossil plants from the upper part of the Middle Romanian deposits, discovered by one of the authors (Enciu) in the neighborhood of Bâcleş locality, brings new information and completes the conspectus of Pliocene flora and vegetation of the southwestern part of Romania.

The first information regarding the Pliocene flora from Oltenia province came from a historical work of Marion and Laurent (1898), which determined two fossil taxa on some samples sent to Paris by G. Ştefanescu. Later, Barbu (1933, 1954 ) added to the Pliocene palaeofloristic inventory other 16 taxa. Further, at the knowledge of Pliocene fossil macroflora from Oltenia have also contributed: Barbu and Givulescu (1964), Givulescu (1966, 1990), Țicleanu (1982, 1985, 1989, 1992) and Țicleanu et al (1985). A complete reviewing of their results was made by Țicleanu (1995).

For the reconstruction of Pliocene fossil flora and vegetation from Oltenia, an important meaning have had also the palynological research made by Roman

\footnotetext{
${ }^{1}$ University of Bucharest, Faculty of Geology and Geophysics, Bd. N. Bălcescu 1, 70111 Bucharest.

2 Institute of Geography of the Romanian Academy, str. D. Racoviță 12, 70307 Bucharest.

${ }^{3}$ Research Institute for Lignite Mining (ICPML), str. Unirii 139, 1100 Craiova.
} 
(in Țicleanu et al, 1982, 1985), Nanii (1982), Petrescu et al (1987, 1989 a, b), Drivaliari (1993), Drivaliari et al (1999).

\section{GEOLOGICAL SETTING}

On the main banks of Argetoaia River and its tributaries, the rare outcrops (Fig. 1) reveal the upper part of the Jiu-Motru Formation, the Cândeşti Formation and the "overlying formation".

Under the local level of erosion, the continuously mechanic drilling for coal prospecting (No 37 and 40, Fig. 1) and for groundwater exploration (No 30 and 32, Fig. 1), crossed the lower part of the Jiu-Motru Formation and then the Berbeşti Formation.

The Berbeşti Formation (Andreescu et al, 1985) consists of about $100 \mathrm{~m}$ thick sandy deposits (with 1-2 m beds of coal). Based on a lot of cardiids (Enciu, 1998), this prevailing fine-medium siliciclastic pile of rocks was reported to the Early Dacian (N2dc1). Over the previous formation, the boreholes revealed a 70$120 \mathrm{~m}$ thick clayey-coaly lithostratigraphic unit, defined as the Jiu-Motru Formation (Andreescu et al, 1985).

As the geological sections reveal (Fig. 1) in the lowermost part of this formation (sample 4614), in the neighborhood of the Rocşoreni village, in the hydrogeological borehole No 30, Dacian brackish mollusks were identified: Horiodacna rumana, Dreissena berbestiensis, Euxinicardium sp. and others.

In the proximity of the Giura village (sample No 4785) and at the base of main Argetoaia valley (sample No 4787), this formation includes varied smooth and sculptured species of the Romanian psilunioninae. In the last site, between 270-275 m a.s.l., Enciu (1998) pointed out an interesting level having fossil plants remains.

Using as proofs the Berbeşti and Jiu-Motru Formations conformity relationship and the above-mentioned list of the brackish and fresh-water mollusks, the last one was assigned to the Upper Dacian - Middle Romanian (N2dc2-ro2).

According to the present stage of our research over the Jiu-Motru Formation, in the surroundings of the Bâcleş locality, it develops the peripheral, south-easternmost edge of the Cândeşti Formation, Upper Romanian - Lower Pleistocene in age (Mrazec \& Teisseyre, 1901; Andreescu, 1971; Alexeeva et al, 1983). This formation was born as a result of the impressive uplift of the Carpathians during the Walachian orogenetic event (Hyppolyte and Săndulescu, 1994; Enciu, 1998, 2000).

Over the Cândeşti Formation, the boreholes for land reclamation projects identified 10-15 m thickness of non-stratified clayey-silty rocks, Middle-Upper Pleistocene in age (named "the overlying formation").

\section{PALAEOBOTANICAL AND TAPHONOMICAL OBSERVATIONS}

The vegetal fossil remains (VFR) from Bâcleş fossiliferous point are found in clays and siltic clays with frequent oxidation traces and a weak tendency of stratification. Although the sedimentation of VFR was made in decantation conditions, a small part of the original vegetal material suffered a short transport (hypautochtony), which made the material to be more or less damaged. In the present paper we determined the following species: 


\section{GEOLOGICAL SECTION ALONG OF THE STREHAIA - BACLES UPLIFT}

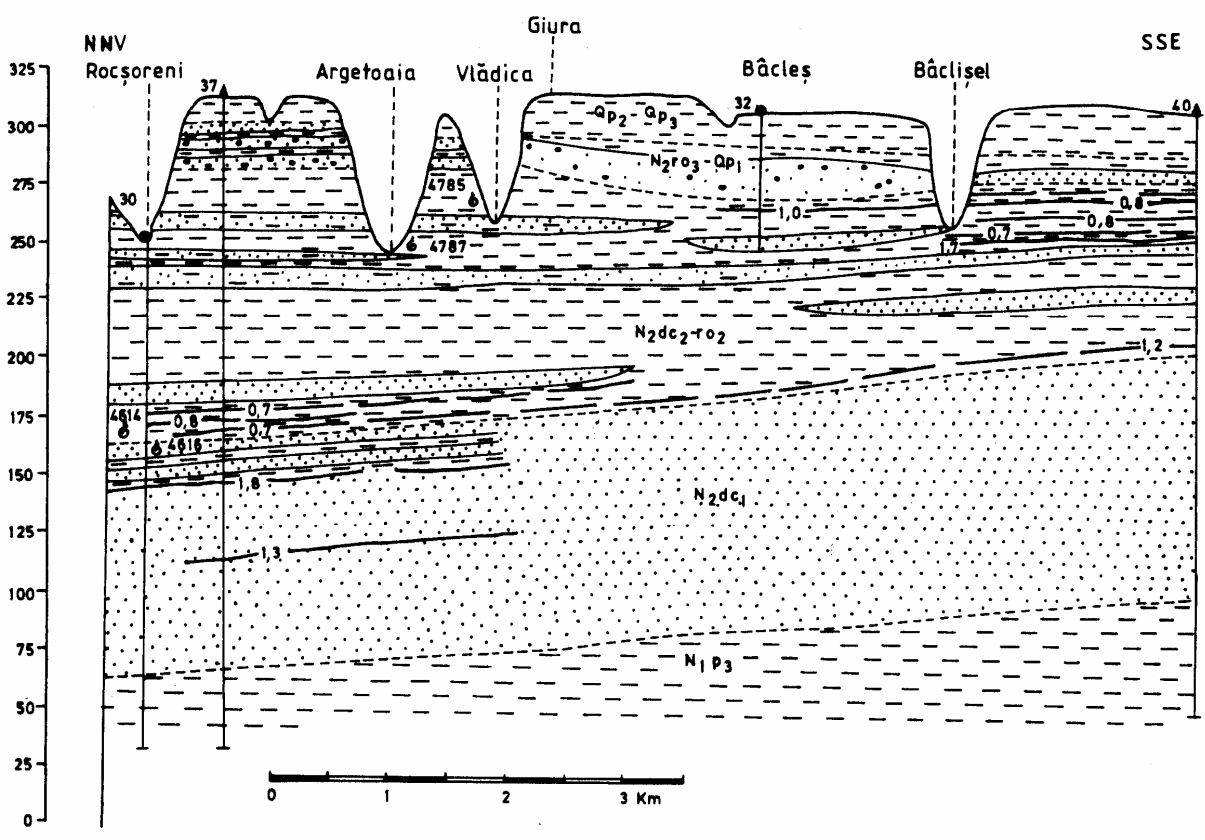

I. STRATIGRAPHIC ELEMENTS

\begin{tabular}{|c|c|}
\hline$\hat{\sigma}_{2}-\hat{\omega}_{3}$ & The Overlying Formation (Middle - Upper Pleistocene) \\
\hline $\mathrm{N}_{z^{\prime}} \circ \mathrm{O}_{3}-\mathrm{Q}_{p_{1}}$ & The Candesti Formation (Upper Romanian - Lower Pleistocene) \\
\hline $\mathrm{N}_{2} \mathrm{de} \mathrm{C}_{2} \mathrm{rO}_{2}$ & The Jiu-Motru Formation (Upper Dacian - Middle Romanian) \\
\hline $\mathrm{N}_{2} \mathrm{~d} \mathrm{c}_{1}$ & The Berbesti Formation (Lower Dacian) \\
\hline$N_{1} P_{3}$ & Ine llovat Formation (Upper Pontian) \\
\hline
\end{tabular}

II. LITHOLOGIC ELEMENTS

\begin{tabular}{ll}
$\because \because$ & Gravels and sands \\
\hdashline & Sandy rocks \\
& Coal $(0,8$ thicness, $\mathrm{m})$
\end{tabular}

III. OTHER SIGNS

$$
\begin{array}{cl}
\int_{b} & \begin{array}{l}
\text { Goological (a) and } \\
\text { hydrogeological boreholes (b) }
\end{array} \\
6 & \text { Number of the paleonto- } \\
4785 & \text { logical sample } \\
--- & \text { Geological boundary } \\
& \text { Lithological boundary }
\end{array}
$$


Taxodium dubium (Sternb.) Heer ?Platanus platanifolia (Ett.) Knobloch

Ulmus laevis L.

Quercus roburoides Gaudin

Quercus cf. muehlenbergii Engelman

Carya serraefolia (Goepp.) Kräusel

Acer cf. tricuspidatum Bronn.

Salix sp.

\section{METHODS}

The palaeofloristic material consists of leaf impressions, the compression being destroyed by oxidation and replaced mostly by limonite. In these conditions, the work method consisted in the drawing on transparent nylon pellicle at the stereomicroscope of all visible details of the morphology of fossil leaves and in macroscopical photography of samples with a good preservation.

\section{SYSTEMATICS}

\section{Phyllum PINOPHYTA}

\section{Clasa PINATAE}

Family TAXODIACEAE

Taxodium dubium (Sternb.) Heer (PI. II, Fig. 2)

Material: 10 samples with the number of inventory: BC-1, BC-4, BC-7, BC-8, BC-21, BC-22, BC-25, BC-26, BC-27 and BC-31.

Description: compressions of the deciduous stems which are branched and covered by scaleous leaves with $0.8-1.5 \mathrm{~cm}$ length and maximum $1 \mathrm{~mm}$ width.

Observations: the VFR of $T$. dubium are the most frequent remains from the Bâcleş fossiliferous point, probably this tree vegetated in the near vicinity of the sedimentation area.

Occurrence in the fossil floras of Romania: it is a rare taxon, being found in Chattian deposits of Petroşani Basin, in Almaşului Basin (Țicleanu, unpubl.), in the Pontian flora of Băița (Ruffle \& Givulescu, 1974), and in the Middle Romanian deposits from Oltenia (Țicleanu, unpubl.).

The actual correspondent: Taxodium distichum (L.) Rich., a 1-st size tree which can reach $50 \mathrm{~m}$ height and live 6000 years; it is a hygrophytic species, well adapted to swamps with almost permanently flooded conditions (11 months/year). The species prefers wet and warm climate, with subtropical or oceanic influences. Today it is spread in the southeastern part of USA, in the swamps of inferior course of Mississippi and in Florida. In Romania, T. distichum is cultivated and now is adapted to the temperate climate. 


\section{Phyllum MAGNOLIOPHYTA \\ Clasa MAGNOLIATAE \\ Family PLATANACEAE \\ ?Platanus platanifolia (Ett.) Knobloch (PI. II, Fig. 1)}

Material: the samples with the number of inventory: BC-16 and BC-17.

Description: the basal part of a leaf with palmate shape (?5 lobes). Palmate nervation. From the primary strong vein of the greatest lobe diverge, close to the base, two lateral veins at the angle of $45^{\circ}$, and from these diverge other two secondary veins, running into the lobes. In the largest lobe, from the primary vein diverge two secondary opposite veins.

Observations: even the original position of the divergence place of the secondary veins is not preserved, a reason to put the genus in discussion. We think that the other characters and the general aspect still represent the taxon $P$. orientalis.

Occurrence in the fossil floras of Romania: the taxon is frequent in the Miocene deposits from Romania.

The actual correspondent: is considered to be $\mathrm{P}$. orientalis, which is a tree with over $30 \mathrm{~m}$ high, and lives in Greece, Asia, Caucasus, Caspian Sea - where in the south forms mixed forests with Zelkova zelkovaefolia and Pterocarya fraxinifolia. It prefers riparian zones with very humid soils.

\section{Family ULMACEAE}

Ulmus laevis L. (PI. I, Fig. 5)

Material: one sample: $\mathrm{BC}-34$.

Description: the inferior part of a foliar impression with ovate shape, strongly asymmetric, pinnate-craspedodromous nervation. The base of the leaf is asymmetric and oblique. The margins and the apex weren't kept. From the primary strong vein diverge 11 pairs of secondary opposite veins. Probably the total number of secondary veins was higher. Some of the secondary veins have a specific bifurcation, which is visible only at Ulmus.

Observations: the general aspect, the asymmetry and the presence of bifurcate secondary veins are characteristics of the genus Ulmus. In the actual flora of Romania, the species $U$. laevis and $U$. foliacea have similar leaf shapes with the fossil. The difference consists in the number of secondary veins: $U$. Laevis have 12 to 19 pairs of secondary veins, and $U$. Foliacea have maximum 12 pairs of secondary veins.

Occurrence in the fossil floras of Romania: $U$. laevis is for the first time cited in the fossil flora of Romania.

The actual correspondent: is considered to be Ulmus laevis L., a tree which is up to $35 \mathrm{~m}$ high, and prefers meadow river forests. It is spread in Europe, from France to Ural Mountains, excepting British Islands and Scandinavian Peninsula.

\section{Family FAGACEAE}

Quercus roburoides Gaudin. (PI. II, Fig. 4)

Material: one sample: BC-33.

Description: the shape of the leaf is obovate and the dimensions are $11 \mathrm{~cm}$ of length and $5 \mathrm{~cm}$ width; it has no apex, with lobate rounded margins and each lobe separated by sinuses incised in laminae up to $1.5 \mathrm{~cm}$. The base is of an auriculate shape. From the strong primary vein diverge? 10 pairs of secondary veins and the 
angle of divergence of the secondary veins decrease from base to apex. The tertiary nervation is orthogonal, reticulated and very obvious.

Observations: taking into account the shape and the rounded aspect of the lobes and the low angle of sinuses, we attribute the specimen to $Q$. roburoides.

Occurrence in the fossil floras of Romania: it is frequent in Pontian and Dacian deposits.

The actual correspondent: is considered to be $Q$. robur L., a 1-st size tree which is spread in the whole Europe, from the Atlantic Ocean to the Urals and to the Caspian Sea, excepting septentrional zones of the Scandinavian Peninsula and the south of the Iberian Peninsula. Q. robur is a tree which resists to xerophytic conditions and forms river plain forests.

\section{Quercus cf. muehlenbergii Engelman (PI. II, Fig. 3)}

Material: one sample: BC-29.

Description: the impression of the superior part of a pinnate-lobate leaf, elongate, asymmetric, with the lobes having the basal side convex and apical side straight, and inter-lobal rounded sinuses. The nervation is pinnate with the primary vein obvious, and alternately secondary veins. The tertiary veins are reticulated.

Observations: the impression keeps enough characters of Quercus type. The specific association was made on the base of the description given by Givulescu (1990).

Occurrence in the fossil floras of Romania: Q. muehlenbergii was cited in the Pontian flora from Chiuzbaia.

The actual correspondent: is considered to be Q. muehlenbergii, which is a tree up to $25 \mathrm{~m}$ high, which lives in the eastern part of USA from the Great Lakes to the Gulf of Mexico, excepting the Florida Peninsula.

\section{Family JUGLANDACEAE}

\section{Carya serraefolia (Goepp.) Kräusel (PI. I, Fig. 1)}

Material: samples BC-28 and BC-29.

Description: the impression and the incomplete compression of a leaf with short elliptic shape ( $8 \mathrm{~cm}$ long and $4 \mathrm{~cm}$ wide) and cunneate base. The nervation is of pinnate-craspedrodome simple type. The primary vein is prominent, slightly curved in the inferior part of the leaf. From the primary vein diverge 10 pairs of secondary veins, which diverge in tertiary veins and therefore on the margin they create a characteristic picture having the shape of " $\mathrm{V}$ " letter, and with the teeth obvious inserted into the serrate margin.

Observations: our exemplar resembles to those described by Givulescu (1969) from Chiuzbaia.

Occurrence in the fossil floras of Romania: very frequent in the Miocene and Pliocene deposits of Romania (after Givulescu and Ghiurcă, 1969).

The actual correspondent: unknown, probably one of the species Carya amara or Carya tomentosa, which are trees up to $25 \mathrm{~m}$ high and live in the river meadow forest and floded zones from USA. 


\section{Family ACERACEAE}

Acer cf. tricuspidatum Bronn. (PI. I, Fig. 2, 3)

Material: samples BC-14, BC-19 and BC-20.

Description: the impression of a trilobated leaf where the margins of lobes are double serrated with the teeth with variable dimension. From the primary vein diverge pairs of secondary veins, which are terminated in the biggest teeth of the margin. Observations: the asymmetric disposal of the lobes, the margin type and the general aspect of the leaf and the nervation represent enough characters for a specific attribution, but the absence of an entire leaf determine us to be uncertain. Our impression resembles to the specimen figured by Buzek (1971).

Occurrence in the fossil floras of Romania: very frequent in the Pliocene deposits of Romania.

The actual correspondent: is considered to be Acer rubrum L., which is a 1-st size hygrophyte tree, widely spread in the eastern part of USA, between Labrador Peninsula and the Great Lakes zone, at north, and the Mississippi Delta and Florida Peninsula, at south. Acer rubrum is a euritherm species, preferring wet soils, especially the swamp zones periodically flooded.

\section{Family SALICACEAE}

Salix sp. (PI. I, Fig. 4)

Material: samples BC-23 and BC-35.

Description: two incomplete foliar impressions, without apex and base, nervation characteristic to the Salix genus with a prominent primary vein, from which diverge secondary veins arched and united towards the margins. Sometimes between those appear intersecondary veins. The network of tertiary veins forms a special arrangement with the veins, which run perpendicularly to the primary vein. The margin of the described leaf seems to be finely and irregularly serrate.

Observations: because of the absence of the entire leaf impression, a specific determination is impossible. The actual ecological affinities of the Salix are for wet soils, living in meadow river zones and in swamp zones periodically flooded.

PALEOPHYTOCOENOTIC AND BIOSTRATIGRAPHIC CONSIDERATIONS

Obviously, the limited number of species doesn't allow too many phytocoenotic considerations, but after the correlation with data from nearby areas, we can say that the discovery of the Bâcleş fossil flora arise some questions regarding the evolution of the flora and vegetation from upper part of the Pliocene.

First of all, we have to mention that is very surprising the high relative number of impressions of Taxodium dubium. Until the present work, Taxodium dubium was known in Oltenia (Țicleanu, unpubl.) only from the deposits covering the VII-th coal seam from Steic microquarry (west of Lupoaia quarry) and the deposits above the XI-th coal seam from Jilt Sud quarry, both coal seams situated in the Lower and Middle Romanian deposits. Both in Steic and in Jilt Sud, Taxodium dubium was found associated with Glyptostrobus europaeus, also a taxodiaceaen, with a large frequency at the Pliocene level (Țicleanu \& Dinulescu, 1999). Relying on the large spreading of Glyptostrobus europaeus and on its absence in the Bâcleş 
fossil flora, we consider that this absence is not accidental, but it has special climatic significance. From the information given by Collani (1926) is known that Glyptostrobus pensilis, the present day correspondent of Glyptostrobus europaeus, doesn't develop and doesn't fructify in the Botanical Garden from Paris, at $11.5^{\circ} \mathrm{C}$ MAT (mean annual temperature). We suppose that it's absence from Bâcleş flora can accord to the decrease of MAT under the limit where this tree can survive. In exchange, Taxodium dubium is more tolerant regarding the temperature.

The last known appearance of Glyptostrobus europaeus accompanied by Byttneriophyllum tiliaefolium, a thermophylous sterculiacean, was found at the level of the XV-th coal seam, in the deposits of Middle Romanian. From here, the conclusion that the cooling of climate under the ecologic limits of Glyptostrobus europaeus, had taken place further of the sedimentation of the XV-th coal seam, most probably in the upper part of Romanian, and the studied flora can be situated in the final part of the Middle Romanian.

Comparing the fossil vegetal association with the present day correspondents, which are usually river meadow trees, we can assume that towards the end of Romanian, at Bâcleş existed a meadow forest with: Taxodium dubium, Quercus muehlenbergii, Carya serraefolia, Ulmus laevis, Platanus orientalis and species of Salix. The presence of Quercus roburoides is another argument for the existence of a flat plain forest.

\section{REFERENCES}

Alexeeva L., Andreescu I., Bandrabur T., Cepaliga A., Ghenea C., Mihăilă N., Troubihin V. (1983), Correlation of the Pliocene and Lower Pleistocene deposits in the Dacic and Euxinic Basins. An. I.G.R., 59, p. 143-151, Bucureşti.

Andreescu I. (1971), Contribuții la stratigrafia Dacianului şi Romanianului din zona de curbură a Carpaților Orientali. D.S.S. Inst. Geol., 58, 4, p. 131-155, Bucureşti.

Andreescu I., Țicleanu N., Pană I., Pauliuc S., Pelin M., Barus T. (1985), Stratigraphie des dépôts pliocènes à charbons, zone est d'Oltenie (secteur Olt-Jiu). An. Univ. Buc., Geol., XXXIV, p. 87-96, Bucureşti.

Barbu I. Z. (1933), Flora fosilă de la Timişani, jud. Gorjiu. Not. Biol., I, 2, p. 37-53, Bucureşti.

Barbu I. Z. (1954), Flora fosilă din Terțiarul Olteniei. An. Com. Geol., XXVII, p. 5-76, Bucureşti.

Barbu I. Z., Givulescu R. (1964), Banisteriaecarpum giganteum (Goepp.) Kr. în Pliocenul superior din R. S. România. St. cerc. geol., geof., geogr., ser. Geol., X, 2, p. 463-466, Bucureşti.

Buzek C. (1971), Tertiary flora from the northern part of the Petipsy area (North Bohemian Basin). Rospr. Ustr. Ust., Geol., 36, 118 p., Praha.

Colani M. (1920), Étude sur les flores tertiaires de quelques gisements de lignite de I'Indochine et du Yunnan. Thèse, Fac. Sc. Paris, 609 p., Hanoi-Haiphong. 


\section{FOSSIL PLANTS FROM ROMANIAN DEPOSITS OF BÂCLEŞ, DOLJ DISTRICT, ROMANIA}

Drivaliari A. (1993), Images polliniques et paléoenvironnements au Néogène supérieur en Méditerranée Orientale; aspects climatiques et paléogéographiques d'un transect longitudinale (de la Roumanie au Delta du Nil). Thèse, Univ. Montpellier II.

Drivaliari A., Ticleanu N., Marinescu F., Mărunteanu M., Suc J.-P. (1999), A Pliocene climatic record at Țicleni (Southwestern Romania). The Pliocene: Time of change. Am. Ass. Stratig. Palyn. Found., p. 103-108.

Enciu P. (1998), Studiul Pliocenului şi Cuaternarului dintre Desnățui şi Jiu. Rez. Teză, 31 p., Univ. "Al. I. Cuza", Iaşi.

Enciu P. (2000), Evoluția sistemului aluvial al Dunării în Pliocen-Pleistocen, proces important pentru cunoaşterea resurselor acvifere din Bazinul Dacic. Proc. Int. Symp. Hydrogeol., p. 81-93, Bucureşti.

Givulescu R. (1966), Fünde von Banisteriaecarpum giganteum (Goepp.) Kr. in Rumänien. N. Jb. Geol. Paläont., Abt. 4, p. 211-214, Stuttgart.

Givulescu R. (1990), Flora fosilă a Miocenului superior de la Chiuzbaia (jud. Maramureş). Acad. Rom., 238 p., Bucureşti.

Givulescu R. (1991), Bemerkungen über die Samaren von Banisteriaecarpum (Goepp.) Kr. Rev. Roum. Géol, 35, Bucureşti.

Givulescu R., Ghiurcă V. (1969), Flora pliocenă de la Chiuzbaia (Maramureş), cu un studiu geologic introductiv. Com. St. Geol., Inst. Geol., Mem., X, 82 p., Bucureşti.

Hyppolyte J. C., Săndulescu M. (1994), Paleostress characterisation of the "Wallachian" phase in its type area (Southeastern Carpathians, Romania). Tectonophysics, 363 p. 235-249.

Marion A. F., Laurent L. (1898), Examinarea unei colecțiuni de vegetale fosile din România. An. Mus. Geol. Pal., p. 186-230, Bucureşti.

Mrazec L., Teisseyre W. (1901), Über Oligozäne klippe am Rande der Karpaten bei Bacău (Moldau). Jahrb. D.k.k., R.A., LI, Wien.

Petrescu I, Codrea V., Pătrutoiu I., Meilescu C. (1987), Contributions à la connaissance de la géologie, de la paléontologie, de la palynologie et de la génèse de formations de charbons du Pliocène supérieur (Romanien) de la zone Roşia-Peşteana-Turceni (Dépt. de Gorj). Studia Univ. Babeş-Bolyai, ser. Geol.-Geogr., XXXII, 2, p. 11-27, Cluj-Napoca.

Petrescu I., Cernita P., Meilescu C., Codrea V., Pascovici N., Vadan M., Hosu A., Manda S. Bengulescu L. (1989-a), Preliminary approaches to the palynology of Lower Pliocene (Dacian) deposits in the Husnicioara area (Mehedinți county, SW Romania). Studia Univ. Babeş-Bolyai, ser. Geol.-Geogr., XXXIV, 2, p. 67-74, Cluj-Napoca.

Petrescu I., Nica T., Filipescu S., Barbu O., Chira C., Avram R., Valaczkai T. (1989-b), Paleoclimatical significance of the palynological approach to the Pliocene deposits of Lupoaia (Gorj county). Studia Univ. Babeş-Bolyai, ser. Geol.-Geogr., XXXIV, 2, p. 75-81, Cluj-Napoca.

Țicleanu N. (1982), On the systematic position of Byttneriophyllum tiliaepholium (Al. Braun) Knobloch et Kvacek and Banisteriacarpum giganteum (Goeppert) Kr. Inst. Geol. Geof., D. S., LXVI, 3, p. 103-114, Bucureşti.

Țicleanu N. (1986), Date preliminare privind studiul paleobotanic al unor foraje de referință pentru cărbunii din Oltenia. Inst. Geol. Geof., D. S., 70-71, 3, p. 236-248, Bucureşti. 
NICOLAE ȚICLEANU, PETRE ENCIU, ION PĂTRUȚOIU, VALENTIN PARASCHIV

Țicleanu N. (1989), Nouvelles données sur la taxinomie, le habitus et l'écologie des taxons Byttneriophyllum tiliaepholium (Al. Braun) Knobloch et Kvacek et Byttneriophyllum giganteum (Goeppert) comb. nov. Studia Univ. Babeş-Bolyai, ser. Geol.-Geogr., XXXIV, 2, Cluj-Napoca.

Țicleanu N. (1992), Studiul genetic al principalelor zăcăminte de cărbuni neogeni din România pe baza paleofitocenozelor caracteristice, cu privire specială la Oltenia. Teză de doctorat, Univ. Buc., 306 p., Bucureşti.

Țicleanu N. (1995), Macroflore et végétation daciènnes du Bassin Dacique. Chronostratigraphie und Neostratotypen, Pliozän P 11, Dazien, Acad. Rom., p. 473-498, Bucureşti.

Țicleanu N., Dinulescu C. (1998), Glyptostrobus europaeus (Brongn.) Heer in the Neogene deposits from Romania. Acta Horti Bot. Buc., 27, p. 215-222, Bucureşti.

Țicleanu N., Huică I., Țicleanu M. (1982), Contributions à la connaissance de la flore Pliocène de la Roumanie, la flore Dacienne de Dedovița (District de Mehedinți). Inst. Geol. Geof., D. S., LXVI, 3, p. 127-143, Bucureşti.

Țicleanu N., Roman S., Givulescu R., Bițoianu C. (1985), Considérations paléofloristiques et pétrographiques sur la génèse des lignites de l'ouest d'Olténie. Inst. Geol. Geof., D. S., LXIX, 4, p. 71-87, Bucureşti.

\section{PLATES}

\section{Plate I}

Fig. 1 - Carya serraefolia (Goepp.) Kr. (x 1.2)

Fig. 2, 3 - Acer cf. tricuspidatum Bronn (x 1.5, x 1)

Fig. 4 - Salix sp. (x 2)

Fig. 5 - Ulmus laevis L. (x 1.5)

\section{Plate II}

Fig. 1 - ?Platanus platanifolia (Ett.) Knobl. (x 1.2)

Fig. 2 - Taxodium dubium (Sternb.) Heer (x 1.5)

Fig. 3 - Quercus cf. muehlenbergii Engelman (x 1.2)

Fig. 4 - Quercus roburoides Gaudin (x 1) 
FOSSIL PLANTS FROM ROMANIAN DEPOSITS OF BÂCLEŞ, DOLJ DISTRICT, ROMANIA

\section{Planşa I}
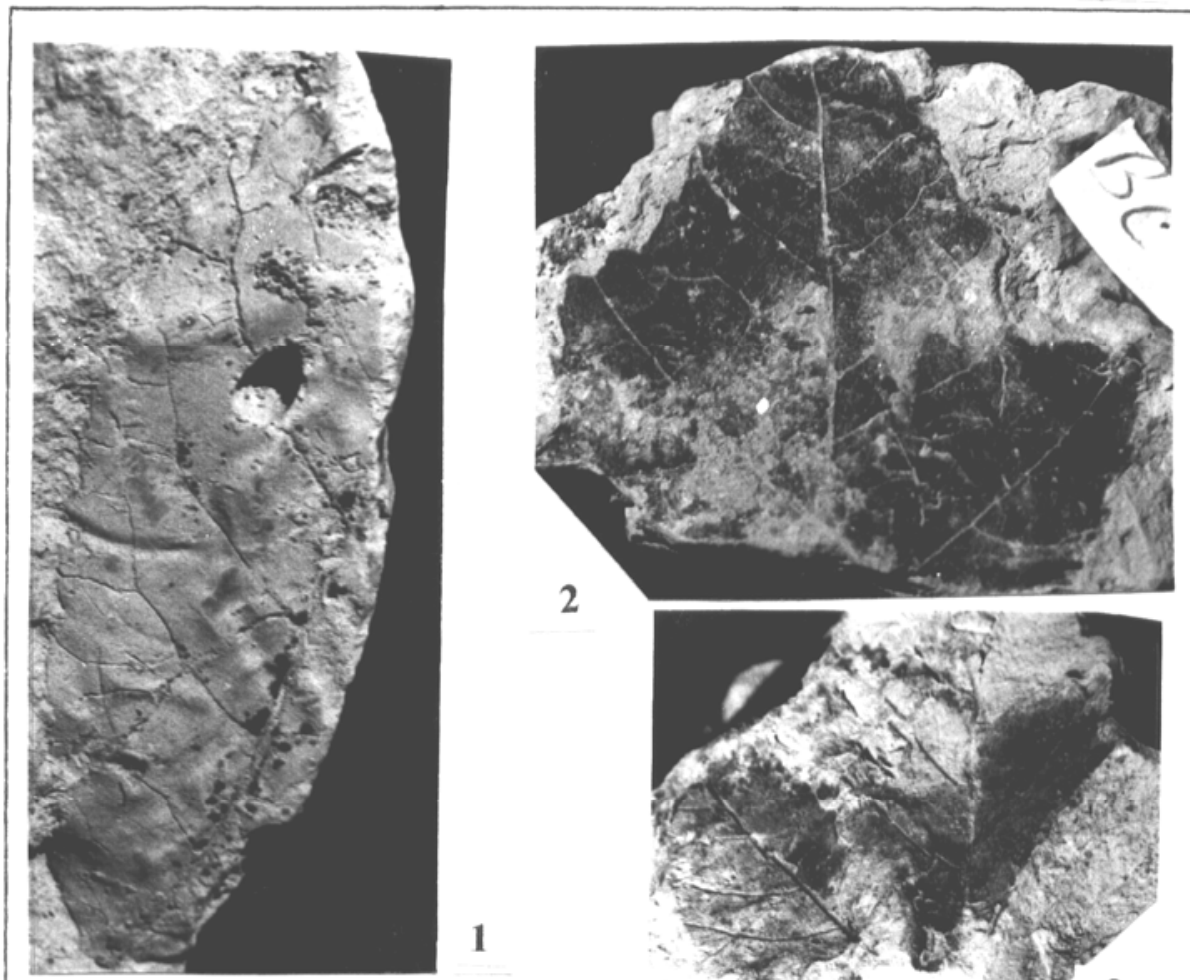

2
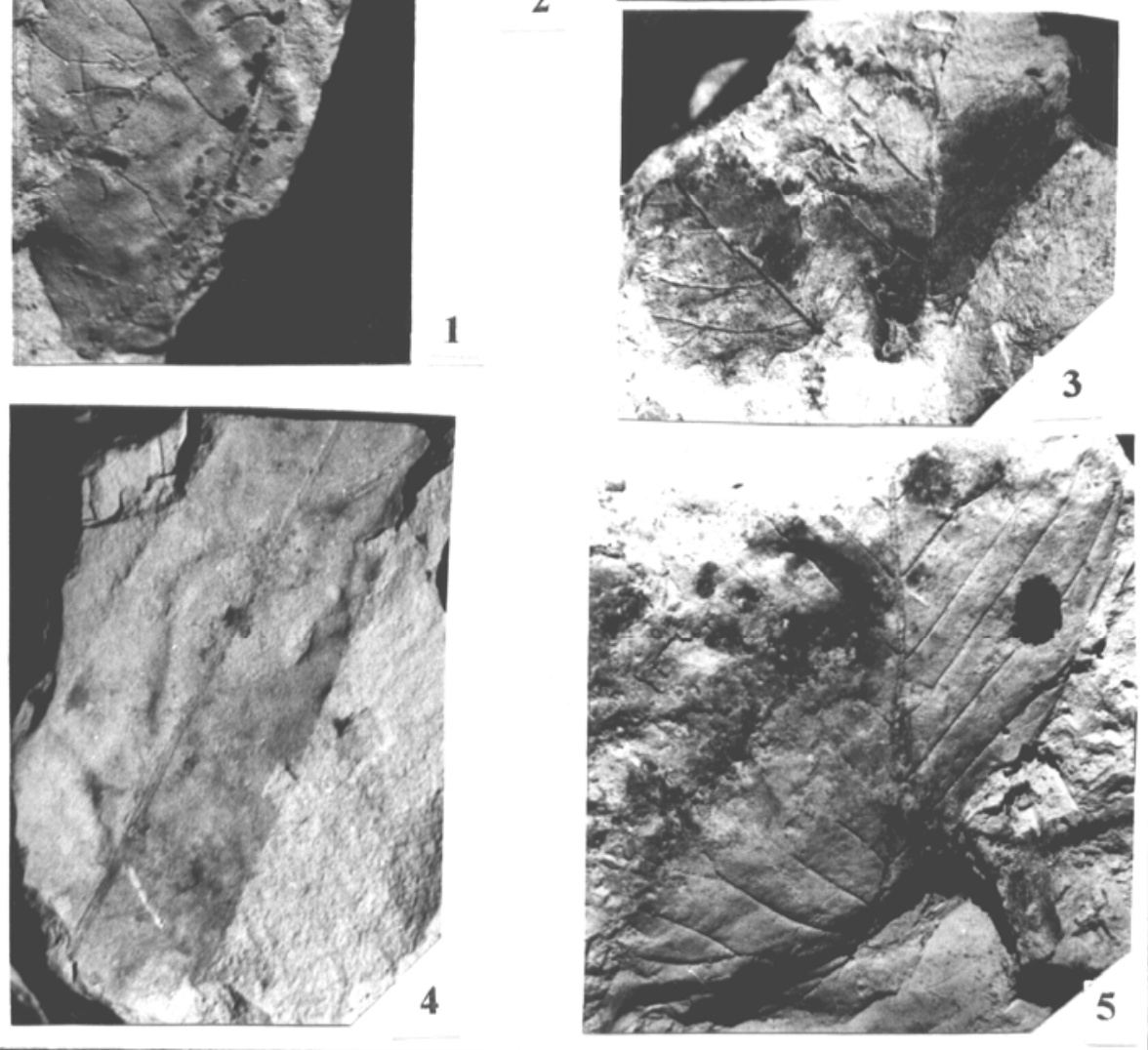
NICOLAE ȚICLEANU, PETRE ENCIU, ION PĂTRUTTOIU, VALENTIN PARASCHIV

Planşa II

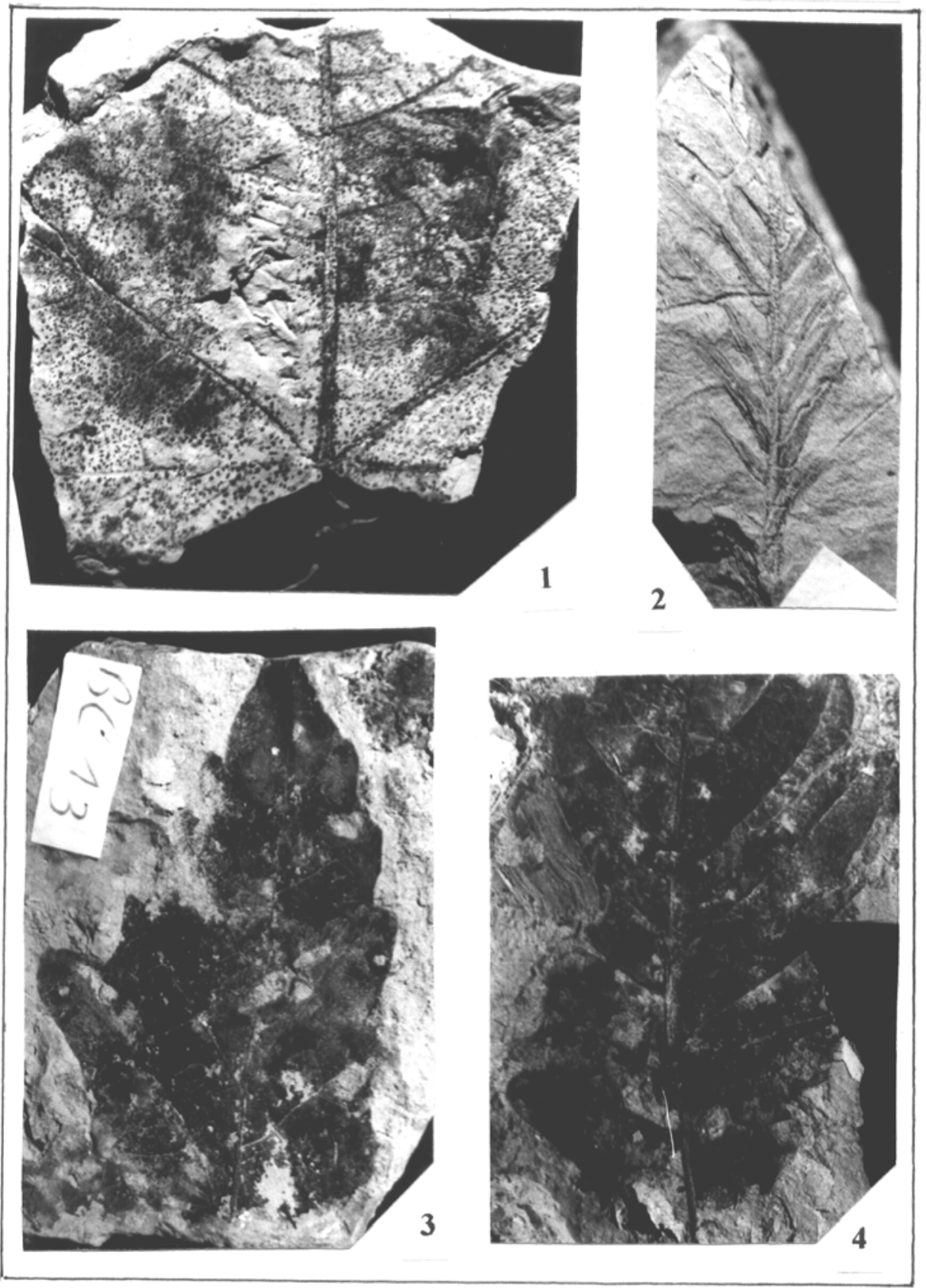

